\title{
Bilişsel Psikoloji, Zihin ve Beyin
}

\section{Tuğba BAKIRTAŞ *}

\author{
Bilişsel Psikoloji, Zihin ve Beyin \\ Edward E. Smith, Stephen M. Kosslyn \\ ed. Muzaffer Şahin \\ Ankara: Nobel Akademik Yayıncılık, 2014, 582 s.
}

\section{$\S \S \S$}

Kitap, Kolombiya Üniversitesi Psikoloji Bölümü profesörü Edward E. Smith ile Harvard Üniversitesi Psikoloji Bölümü profesörü Stephen M. Kosslyn'ın kolektif bir şekilde İngilizce olarak 2010 yılında en son gelişmelerin ışığında kaleme almış oldukları eserin 2014 yılında çeviri grubunun bir yıllık çalışması neticesinde Türkçeye çevrilmiş halidir.

Değerlendirecek olduğumuz bu kitap:“Önsöz, Beyin Zihinsel Faaliyetlere Nasıl Yol AçarAracılık Eder, Algı, Dikkat, Uzun Süreli Belleğin Temsili ve Bilgisi, Kodlama ve Uzun Süreli Bellekten Geri Çağırma, Çalışma Belleği, Yürütücü İşlemler, Duygu ve Biliş, Karar Verme, Problem Çözme ve Akıl Yürütme, Motor Biliş ve Zihinsel Benzetim, Dil" bölümlerinden oluşmaktadır.

2002 yılında kaleme alınan kitabın her bir bölümü kendi alanlarında uzman olan psikologlar tarafından yazılmıştır. Sekiz yıllık bir çalışmanın sonucunda; sinirbilimi, bilişsel psikoloji içerisinde ele alarak bu alanda ilk ders kitaplarından birisi olma niteliğini taşımaktadır.

Yazarlar, önsöz kısmında kitabın yazııma amacının öğrencilere bilişsel psikoloji alanında heyecan uyandırıcı yeni çalışma bulgularını sunmak ve alandaki kilit konulara öğrencilerin dikkatini çekmek olduğunu belirtmektedirler ( $\mathrm{s}$. Xiii). Kitap, güncel konularla zenginleştirilerek öğrencilerin konuyu en iyi şekilde öğrenmelerini hedeflemektedir. Her bir bölüme "Tartışma, Daha Yakından İnceleyelim, Öğrenme Hedefleri, Özet, Eleştirel Düşünme Soruları" başlıkları eklenerek konuların daha açık anlaşılması ve uzun süreli belleğe aktarımının kolaylaşması amaçlanmaktadır. Yazarlar, her bir bölümde o bölümün olay örgüsü ile bağlantılı gündelik yaşamdan bir hikâye ile başlayarak okuyucunun dikkatini cezp etmekte ve konuların modern bilişsel deneylerle zenginleştirilmesi ile anlaşılmasını kolaylaştırmaktadırlar.

Kitabı, kendi alanındaki diğer kitaplardan ayıran en önemli özelliği; geleneksel bakış açısını bir kenara bırakıp bilişsel bakış açısından kaleme alınmış olması ve içerisinde daha önceki kitaplarda yer almayan "duygu" ile ilgili bir bölümün bulunmasıdır.

Psikolojinin kavram olarak ortaya çıkış safhalarına baktığımızda şu evreleri görmekteyiz. Felsefi bakış açısından filozoflar psykhe'yi ruh olarak değerlendirilmektedir. Ortaçağ filozoflarından olan Thomas Aquinas insanı beden ve zihin birleşiminden ele alıp zihnin daha önemli olduğunu vurgulamaktadır. Rönesans düşünürleri ile birlikte felsefi bakış terk edilerek psykhe zihin olarak nitelendirilmiştir. 1879 yılına gelindiğinde ise Wilhelm Wundt'un ilk modern

\footnotetext{
* Sakarya Üniversitesi, Sosyal Bilimler Enstitüsü, Felsefe ve Din Bilimleri, Din Psikolojisi, Yüksek Lisans Öğrencisi e-posta: $\underline{\text { sautuba@gmail.com }}$
} 
psikoloji laboratuarı ile birlikte bilincin doğası incelenmeye başlanmış ve psykhe bilinç olarak ifade edilmiştir. Yazarların da ifade ettiği gibi; John Watson ile birlikte psikolojinin örtük davranışları araştırmaktan ziyade gözle görülür elle tutulur süreçleri incelemesi gerektiği bildirilerek, psykhe davranış olarak kabul görmüştür (s. 6). 1950'lerin sonuna gelindiğinde ise davranış̧̧ı yaklaşımın sınırları bu ekolun terk edilmesine neden olmuştur. Bilgisayarın icat edilmesi ile "bilişsel devrim" gerçekleşmiş ve insan davranışları uyarıcı tepki bağlamından farkı bir şekilde ele alınmaya başlanmıştır. Artık bilişsel süreçler irdelenmekte ve bilişin davranışlar üzerindeki tesiri açıklanmaktadır. Psykhe bu süreçte biliş olarak ele alınmaktadır. Günümüzde ise bilişsel nörobilim faaliyetlerinin artması ile psykhe biliş/beyin ekseninde izah edilmektedir. Yazarlar ise burada psikoloji kavramını modern bir izah olarak biliş/beyin ekseninde ele alıp, insan davranışlarını nörobilim kapsamında izah etmeye çalışıımaktadırlar.

Yazarlar, birinci bölümde kitaptaki konuların çoğunun filozoflar için eski olduğunu belirtmektedirler (s. 3). Antikçağda bu gün bildiğimiz söylenmeyen hiçbir şey yoktur da diyebiliriz. Sokrates, Platon, Aristoteles, Galen, Descartes gibi düşünürler psikolojinin temel sorularını ve problemlerini ele almış ve incelemeyi amaçlamışlardır. Ancak onlar bu konuları ele alıp incelerken felsefi bakış açısı ile değerlendirmişlerdir, hâlbuki günümüz bilim anlayışı deney ve gözleme dayalı bilimsel bir bilim ortaya koymayı amaçlamaktadır.

Yazarlar, zihnin bir makine gibi değerlendirilmemesi gerektiğini vurgulamaktadırlar. Her ne kadar bilişsel devrim ve bilgisayarın icadı ile bilişsel süreçlerin incelenmesi ön plana geçse de bilgisayar yapay bir zekâdır, insan zihni ise karmaşık ve düşünsel bir yapıyı teşkil etmektedir. Yazarlar, bilişsel nörobilimi; beynin bütün olarak işlevi ve ayrı ayrı yapılarının işlevleri ile bunların birbirleri ile entegrasyonu olarak tanımlamaktadırlar (s. 25). Bu şekilde bir tanım yapıldıktan sonra bilişi tam manasıyla kavramak için hangi yöntemlerin kullanıldığını, kullanılması gerektiğini, bu yöntemlerin sınırılıklarını ve beynin ne tür faaliyetlerini analiz ederken dikkate alınması gerektiğini ifade etmektedirler. Yazarlar, birinci bölüme yöntem bilim içeriğini eklemeleri ile diğer bilişsel psikoloji alan kitaplarında olmayan bir farklılık ortaya koymuşlardır.

Genel olarak kitap, bilişsel süreçlerimizin neler olduğunu, bu süreçlerin nasıl işlediğini, beynimizin hangi bölgesinin ne tür işlevlere sahip olduğunu ve bu bölgelerin davranışlarımızı ne şekilde yönlendirdiğini ifade etmeye çalışmaktadır. Davranış, zihinsel bir faaliyettir, zihin bedene herhangi bir komut vermeden bedenin hareket etmesi, parmağını dahi oynatması mümkün gözükmemektedir. Basit gibi görünen pek çok işlemin arkasında karmaşık bir bilişsel süreç yer almaktadır (s. 18-26)

Beyin, hayatı anlamlı yapan en önemli organ konumundadır. Hatırlamanın, hissetmenin, kavramanın, akletmenin, karar vermenin, dikkatin, belleğin ve bütün bilişsel süreçlerin ön şartıdır. Hatta duygularımızın dahi hissedilmesinin yegâne nedeni ve anahtarıdır. Kitapta da ifade edildiği şekliyle yapılan araştırmalar, duygu içerikli ifadelerin algısı için belli nöral sistemlerin özelleştiğini ve harekete geçtiğini göstermektedir (s. 329).

Beyin, birbiri ile etkileşim içerisinde olan pek çok nörondan oluşmaktadır. Bu nöronlar elektriksel uyarımlar neticesinde bilişsel süreçlerimizi meydana getirmektedir. Karar vermenin dahi beyindeki pek çok noktayı harekete geçirdiği ve tek bir bölgenin o işleve has kılınmadığı tespit edilmiştir (s. 408). Bu durum en basit eylemlerimizin bile beynimizin kolektif çalışan yapıları sonucu meydana geldiğini göstermektedir.

Yazarlar, genel bir şablon ile bilişsel süreçleri, pozitif bilim anlayışına uygun bir biçimde, deneysel ve nörobilimsel bir gözle izah etmeye çalışmaktadırlar. Belli bilgi birikimi olan herkese hitap edecek tarzda hazırlanmış olup, kullanılan akıcı ve anlaşıı dil ile konuların kavranması kolaylaşmaktadır. Ancak bazı bölümlerde konunun yeterli derecede anlatılmadan örnek ve deney kısmına geçilmesi, bilişsel psikolojiyle ilgili bilgi birikimi olmayan kişiler için anlaşılmayı zorlaştırmaktadır. Her bir bölümdeki özet kısımlarında bilişsel süreçler genel hatlarıyla aktarılsa da, aynı hassasiyetin bölüm içeriklerine yeterli şekilde yerleştirilememesi konu içeriğini sınırlandırmaktadır. 
Bilişsel süreçlerimizi psikolojik bakış açısıyla ele alıp açıklayan eser, algıladığımız dünyanın içimizde olduğu fikrini bilinçaltımıza yerleştirmektedir. Dış dünyada ne bir ses, ne renk, ne şekil, ne korku ne de biçim mevcuttur; bunların hepsi bireyin duyu ve algı süreçleri ile kavradığı, beyninde şekillendirdiği kanaatleridir. Yazarlar bilgi birikimi, çevre, kültür, sosyal ilişkiler, eğitim gibi dış etkenlerin dahi algılarımıza etki ettiğini belirtmektedirler (s. 101).

Günümüz modern bakış açısıyla yapılan deney ve incelemeler çok kısıtlıdır ve araştırmalar beynin çok küçük bir bölümünün ne işe yaradığının tespit edilebildiğini ortaya koymuştur. Yazarlar bu tür tespitlerden sonra pek çok yeni araştırmaya intiyaç olduğunu, beynin ve davranışların nasıl şekillendiğini bulmak için yeni deneyler yapılması gerektiğini izah etmektedirler.

Beyin gizemini, ruh bilinmezliğini, davranışlar karmaşıklığını korudukça; insanda da bu öğrenme ve bilinmeyeni açma merakı oldukça, bu alanda daha pek çok bilimsel çalışmaya intiyaç duyulacaktır.

Netice itibariyle kitap, nörobilim bakış açısıyla alanındaki ilk ders kitabı olma özelliğine sahiptir. Çeviri grubunun özverili çalışması ile anlaşıır bir metin ortaya çıkmaktadır. Belli bilgi birikimi olan herkesin rahat bir şekilde okuyup anlayabileceği şekilde tercüme edilmektedir. Ancak kitap oluşturulurken yeterli düzeyde deneylerle zenginleştirilmemesi bir eksiklik olarak karşımıza çıkmaktadır. Her bir bölüm farklı bir konu ile ilgili olduğu için, kitap içerisinde çok fazla tekrara da gidilmemektedir. Bu durum da eserin akıcılığını ve anlaşıırığını kolaylaştırmaktadır. 